\title{
Methionine Synthase
}

National Cancer Institute

\section{Source}

National Cancer Institute. Methionine Synthase. NCI Thesaurus. Code C104949.

Methionine synthase (1265 aa, $141 \mathrm{kDa}$ ) is encoded by the human MTR gene. This protein plays a role in the methylation of homocysteine. 